DOI

http://dx.doi.org/10.1590/2236-463320151006

Modulating the Historical Time:

Bernardo Pereira de Vasconcelos and

the Concept of "return" in Brazilian

Parliamentary Debate" (1838-1840)

\section{Modulando o tempo histórico: Bernardo Pereira de Vasconcelos e conceito de "regresso" no debate parlamentar brasileiro (1838-1840)}

Christian Edward Cyril Lynch ${ }^{1}$

Universidade do Estado do Rio de Janeiro, Rio de Janeiro - RJ, Brasil e-mail: clynch3@hotmail.com
Christian E. C. Lynch é professor do Instituto de Estudos Sociais e Políticos da Universidade do Estado do Rio de Janeiro (IESP-UERJ, antigo IUPERJ) e pesquisador da Fundação da Casa de Rui Barbosa (FCRB) e do Conselho Nacional de Desenvolvimento Científico e Tecnológico (CNPq).

\section{Resumo}

Este artigo tem por objetivo examinar os sentidos do conceito de regresso empregado no Parlamento brasileiro no final da década de 1830, no contexto da temporalização da política partidária. Ao final, pretendese indagar se o "regresso" constituiu uma "reação" no sentido então consagrado por Benjamin Constant: tentativa de fazer retroceder o curso da história e retornar ao absolutismo. Particular atenção é aqui concedida ao pensamento de Bernardo Pereira de Vasconcelos, liberal renegado e principal teórico do chamado "sistema do regresso".

\section{Abstract}

This article aims to examine the way the concept of "regress" (return) used in the Brazilian Parliament in the late 1830s, in the context of the temporalization of partisan politics. At the end, we intend to investigate whether the "return" was a "reaction" as defined by Benjamin Constant: an attempt to turn back the course of history and return to absolutism. Particular attention is given here to the thought of Bernardo Pereira de Vasconcelos, liberal renegade and chief theoretician of the "system of return".

Palavras-chave

Bernardo Pereira de Vasconcelos, história dos conceitos, história do Brasil, regresso, reação

\section{Keywords}

Bernardo Pereira de Vasconcelos, history of concepts, History of Brazil, return, reaction 
2

"Gigante intelectual, na definição de Nabuco, sustentáculo da monarquia representativa, teórico do liberalismo conservador em política e economia, construtor de instituições, mas também avesso à democracia, à igualdade social e insensivel à sorte dos escravos, tudo isso foi Vasconcelos. Admirado, temido e odiado, não deixou ninguém indiferente à sua passagem". CARVALHO, José Murilo de. Introdução. In: VASCONCELOS, Bernardo Pereira de. Bernardo Pereira de Vasconcelos. Organização e Introdução de José Murilo de Carvalho. São Paulo: Editora 34. p.34.

3

Não tenho a intenção, nem de biografar, nem de exaurir o pensamento político de Vasconcelos para além do periodo. Centro-me em seus pronunciamentos parlamentares entre 18381840, de modo a contextualizar de modo o mais fidedigno possivel o conceito de regresso por ele mobilizado na arena legislativa. Como em outros textos meus, mobilizo a história política não como um fim em si, mas como moldura (por certo indispensável) à compreensão fidedigna do pensamento político de uma determinada época.
Introdução

Este artigo tem por objetivo examinar o conceito de regresso manejado pelos principais atores político brasileiros durante a virada conservadora da década de 1830. É no intuito particular de se averiguar a temporalização dos conceitos políticos no Brasil da década de 1830 que se estudará aqui o conceito de regresso. 0 objetivo é o de responder à seguinte indagação: era o "regresso" brasileiro uma "reação", isto é, uma tentativa de fazer retroceder o curso da história e retornar ao Antigo Regime? Em primeiro lugar, farei uma breve descrição da virada conservadora que teve lugar em diversos países cêntricos e periféricos, depois do primeiro ímpeto revolucionário, a fim de contextualizar o movimento do regresso no Brasil. Em seguida, 0 artigo se debruçará sobre os anais da Assembleia Geral Legislativa, ou seja, da Câmara dos Deputados e do Senado do Império, entre os anos cruciais de 1838 e 1840. Particular atenção será concedida ao pensamento de Bernardo Pereira de Vasconcelos, principal formulador teórico do "sistema do regresso"2. Essa atenção se justifica, entre outros motivos, pela importância que o movimento teria na criação de um modelo político - saquarema que logrou institucionalizar-se e garantir a ordem imperial pelos trinta anos seguintes, quando começou a ser desmontado. ${ }^{3}$

A metodologia empregada é aquela da história dos conceitos de Reinhart Koselleck, para quem o conceito seria uma ferramenta fundamental para a inteligibilidade do fenômeno humano. A partir delas, aquele estudioso criou em projeto historiográfico a descoberta da historicidade intrínseca à experiência na modernidade, projeto este dos mais importantes para uma captura adequada das mudanças ocorridas no campo do pensamento político. Para Koselleck, há um período particularmente digno de estudo conceitual: aquele por ele denominado Sattelzeit (1750-1850). Este termo designa o período de transição sofrido pelo sistema político conceitual do Antigo Regime para o constitucionalismo e liberalismo. Acompanhando as transformações socioeconômicas ocorridas na Europa ocidental, os conceitos políticos teriam sofrido durante aquele século quatro grandes processos: a democratização (alargamento do seu campo de uso por camadas até então alijadas); temporalização (os conceitos passaram a ter o futuro e não mais o passado como referência); ideologização (os conceitos perdem sua dimensão concreta para se tornarem cada vez mais abstratos) e politização (os conceitos passam a adquirir acentuada polissemia por seu emprego por diversos setores na arena política).

\section{A dialética revolucionária da modernidade: a virada conservadora no mundo iberoamericano oitocentista.}

Embora a filosofia do progresso histórico já estivesse consolidada na década de 1830, parte considerável da classe política do mundo ibérico e ibero-americano experimentou por esse tempo uma virada conservadora em matéria de política. Tais setores acreditavam que a orientação intelectual que prevalecera durante o processo revolucionário e ajudara a derrocar o Antigo Regime não se revelara de idêntica utilidade quando se tratou de criar uma ordem constitucional estável. Sob o pretexto de eliminar a fonte do despotismo que oprimia a sociedade- 0 absolutismo -, o governo acabara tão enfraquecido pelas reformas liberais que se passara a sofrer do mal oposto: a anarquia, por tal entendendo-se a escalada da violência, a impunidade generalizada, rebeliões constantes, quando não a própria guerra civil. Chegara, portanto, o momento de fazer a crítica do liberalismo 
4

CAMPOS HERRIET, Fernando. Historia Constitucional de Chile. Tercera edición. Santiago: Editorial Juridica de Chile, 1963. p.115.

5

Não quero aqui dizer que os significados dessa virada conservadora sejam os mesmos para todos os paises dos dois continentes do mundo ibérico. A despeito do clima intelectual geral de reação contra o liberalismo radical, há diferenças entre os paises ibéricos da Europa e da América. $\mathrm{Na}$ Europa, a necessidade de restabelecimento da ordem se dava no contexto de duas monarquias que tinham raizes muito antigas, ao passo que na América eram paises muito novos, quase todos repúblicas, embora mais atrasados que as antigas metrópoles. Por isso, os paises ibero-americanos eram mais dependentes da ideologia liberal, que se confundia com as independências que lhes havia dado origem. 0 discurso liberal conservador na América teve portanto de apresentar-se em suas linhas gerais mais progressista, mais comprometido com a construção nacional e com o futuro, do que na Europa, conforme insinuo no final do artigo. E isto ocorreu mesmo no Brasil, que era, como a Espanha e Portugal, uma monarquia constitucional. LYNCH, Christian Edward Cyril. Monarquia sem Despotismo e Liberdade sem Anarquia: o pensamento político do marquês de Caravelas. Belo Horizonte: Editora da UFMG, 2014. Pode-se mesmo avançar que, no Brasil, o conservadorismo foi, comparativamente, dos mais progressistas no conjunto do mundo ibérico - justamente porque, na medida em que era uma monarquia cercada de repúblicas no Novo Mundo, o regime era obrigado constantemente a apresentar as suas credenciais liberais. Idem. Da Monarquia à Oligarquia: história institucional e pensamento político brasileiro (1822-1930). Prefácio de Pierre Rosanvallon. São Paulo: Alameda, 2014. p.67.

6

SUANZES-CARPEGNA, Joaquin Varela. Política y Constitución en España (1808-1978). Prólogo de Francisco Rubio Llorente. Madrid: Centro de Estudios Políticos y Constitucionales, 2007. p.85.

lbidem, p.94

SILVA, António Martins da. A vitória definitiva do liberalismo e a instabilidade constitucional: cartismo, setembrismo e cabralismo. In: MATTOSO, José (dir.). História de Portugal. Volume 5: 0 liberalismo. Lisboa: Editorial Estampa, 1998. p.88 e p.89. radical, de índole jusnaturalista, racionalista, universalista e metafísico, para reconhecer o peso das realidades e forjar uma ordem institucional que, fortalecendo o Estado, Ihe fornecesse meios de restabelecer a paz, periclitante desde a Revolução.

Para além do próprio instinto pragmático de sobrevivência, essa guinada conservadora pôde ser teorizada e justificada a partir de dois grandes precedentes, um norte-americano, e o outro, francês. Na década de 1780-1790, os federalistas estadunidenses haviam promovido uma campanha destinada a neutralizar os excessos do liberalismo radical que, tendo justificado a independência das antigas treze colônias, haviam, entretanto, criado uma situação de desgoverno que ameaçava a União americana. 0 resultado da campanha fora a nova Constituição de 1787, que criara uma União Federal fortalecida, tendo os federalistas, responsáveis por aquela guinada, dominado a cena política nacional pelos anos seguintes. 0 segundo precedente era o da França, onde a situação era mais complicada: desde 1795 se vinha lá tentando encerrar o processo revolucionário, por meio de um arranjo que equilibrasse as necessidades de liberdade com a ordem pública. Depois de diversas tentativas, desde o Termidor até a restauração dos Bourbons, passando pelo Consulado e pelo Império napoleônico, os franceses pareciam finalmente ter encontrado aquele balanço graças à Monarquia de Julho, teorizada e justificada pelo liberalismo doutrinário (conservador) de François Guizot.

Com os dois precedentes em vista, o imperativo de restabelecimento da paz perdida na época pós-revolucionária levou os antigos partidos liberais, que haviam sido responsáveis pela queda do despotismo no mundo ibérico e ibero-americano da década de 1830,a uma crise que terminou quase sempre pela sua cisão. As antigas alas direitas dos partidos liberais, uma vez emancipadas, formaram novas agremiações, de orientação conservadora, cujo propósito declarado era o de fortalecer o poder executivo, a fim de estabelecer um equilibrio entre os extremos do liberalismo e do absolutismo. Na América Ibérica, era o Chile quem oferecia o exemplo de virada conservadora. Depois de sete anos de instabilidade, durante a qual se sucederam trinta governos e três constituições, a Revolução de 1829 trouxe ao poder um partido formado pela aliança político-militar dos antigos pelucones com os estanqueros, que derrotou os liberais (ditos pipiolos) na batalha de Lircay. ${ }^{4} 0$ resultado foi a Constituição de 1833, que instaurou uma verdadeira república monárquica, cujos poderes estavam centralizados nas mãos do Presidente. Começava um longo regime cujas bases só erodiriam na década de $1860 .{ }^{5} \mathrm{Na}$ Espanha, os progressistas abandonaram a ala radical do partido liberal (dita dozeanista), que preferia voltar à Constituição radical de 1812, e se compuseram com a antiga direita constitucional "moderada", para elaborar a nova Constituição de 1837, de caráter compromissório. ${ }^{6}$ Tal não impediu que a direita moderada mais tarde passasse 0 rolo compressor sobre os progressistas e os radicais, instaurando em 1845 um regime ainda mais conservador, que daria o tom da política espanhola até 1868.' Portugal seguiu a esteira da Espanha: depois da Revolução de 1838:boa parte do antigo partido liberal desistiu da restauração da Constituição de 1822, desejada pelos radicais, preferindo costurar a Constituição compromissória de 1838 com os moderados (chamados "cartistas"). A guinada à direita se completou quatro anos depois, quando se restabeleceu a Carta constitucional de 1826 e, com ela, o domínio dos referidos cartistas chefiados por Costa Cabral. ${ }^{8}$ 
9

WOOD, Gordon S. The Creation of the American Republic. The University of North Carolina Press, 1998. p.437.

10

FURET, François. La Revolution Française II: Terminer la Révolution. De Louis XVIII á Jules Ferry (1814-1880). Paris: Hachette, 1988. p.188.

11

FERNANDEZ SEBASTIAN, Javier. Progressista. In:__ _ FUENTES, Juan Francisco (dirs).

Diccionario político y social del siglo XIX español. Madrid: Alianza Edittorial, 2002. p.557.

12

MONTEIRO, Nuno; RAMOS, Rui. El liberalismo em Portugal en el siglo XIX. In: FERNANDEZ SEBASTIÁN, Javier. La Aurora de la Libertad: Ios primeiros liberalismos em el mundo iberoamericanos. Madrid: Marcial Pons História, 2012. p.398.

13

FREYRE SERRANO, Ramón. El ciudadano Ramón Freyre a sus concidaudanos. Lima: Imprenta de José Maria Mastar, 1831. p.2.

14

LYNCH, Christian Edward Cyril. Do Despotismo da Gentalha à Democracia da Gravata Lavada: História do Conceito de Democracia no Brasil (1770-1870). DADOS - Revista de Ciências Sociais, Rio de Janeiro, v.54, n.3, 2011.

15

DOHLNIKOFF, Miriam. O Pacto Imperial: origens do federalismo no Brasil. São Paulo: Editora Globo, 2005. p.72.

16

CARVALHO, José Murilo de. A Construção da Ordem: a elite politica imperial. Teatro de Sombras: a política imperial. 2a. edição revista. Rio de Janeiro: Editora UFRJ, Relume Dumará, 1996. p.231.
Apeados do poder, em toda a parte os liberais se recusaram a aceitar passivamente a interpretação conservadora relativa às causas da anarquia ou a responsabilidade dela decorrente. Para eles, a revolução que derrocara o despotismo fora uma "ação" que, ao instaurar a liberdade, promovera o progresso nacional e inscrevera seus países na marcha da civilização universal. 0 movimento conservador subsequente era caracterizado como uma tentativa de fazer retrogradar o tempo histórico para a época do despotismo- isto é, uma "reação". Nos Estados Unidos de 1787-1789, as propostas dos federalistas (unionistas) foram acusadas pelos antifederalistas (estadualistas) de reverter "as tendências democráticas das constituições anteriores", com o fito de "recuperar os contornos aristocráticos e monárquicos dos antigos governos coloniais"9. Na França, desde o começo da década de 1830 a oposição dinástica atribuía, aos doutrinários, a pretensão de interromper a irresistível revolução democrática em curso. ${ }^{10}$ No mundo ibérico dos dois continentes, os conservadores também foram denunciados como promotores de uma "reação". Na Espanha, foram acusados de aferrarem-se a "princípios de outras épocas" e de tentarem "fazer volver atrás a despenhada corrente dos anos"11; em Portugal, de governarem de modo análogo ao antigo "despotismo"12; no Chile, de restaurarem as práticas dos "antigos opressores e dilapidadores da nossa Pátria"13.

Na segunda metade da década de 1830, um movimento similar tomou corpo no Brasil. No poder, desde a abdicação de Dom Pedro I, o partido liberal reformara diversos pontos da legislação imperial conforme uma orientação mais "democrática", ou seja, favorável à descentralização política, transferindo-se às províncias o controle sobre a polícia, o judiciário local e o direito de legislar sobre atribuições de interesse local. ${ }^{14}$ Porque instituíra uma forma semifederativa de Estado no Brasil, o Ato Adicional de 1834 representara o zênite desse processo. ${ }^{15}$ No entanto, o aprofundamento de conflitos armados em várias províncias logo forneceu à ala mais moderada do partido liberal argumentos para criticar as reformas que haviam sido capitaneadas pela ala mais progressista. Chefiada por Bernardo Pereira de Vasconcelos, a seção direita do partido rompeu com o governo do Regente, Diogo Antônio Feijó, chefe da ala esquerda, e o derrubou no ano seguinte. Nomeado ministro da Justiça, Vasconcelos começou em setembro de 1837 a promoveras mudanças inscritas no programa do chamado Regresso, destinadas a desfazer ou corrigir os excessos do reformismo liberal. Eram elas: frear o avanço das províncias sobre as competências da União; retirar das províncias o controle da polícia e do judiciário de primeira instância, devolvendo-o à União; e, por fim, unificar a cadeia de comando no plano da União, subordinando o Judiciário e o Legislativo ao Executivo. ${ }^{16}$ As sessões parlamentares de 1838 e 1839 , de hegemonia do grupo de Vasconcelos, foram atravessadas pelo tema do "regresso", que se tornou um conceito chave para se compreender as mudanças na política brasileira, polarizando-a entre a situação regressista e a oposição progressista. Estes seriam os núcleos dos partidos que dominariam a cena política até o final do Império: o conservador ou saquarema, e o liberal ou luzia. Dai a importância de examinarmos os diversos usos e sentidos semânticos do conceito de regresso nos discursos parlamentares daqueles dois anos.

No Senado, o debate era particularmente virulento, porque nele se achavam os chefes mais importantes do país, outrora aliados no partido liberal moderado, e agora divididos pelo "regresso". Lamentava o senador mineiro Felisberto Caldeira Brandt, Marquês de Barbacena: "A nação está 
17

ANAIS DO SENADO DO IMPÉRIO, sessão de 14 de junho de 1839. Rio de Janeiro, Tipografia Nacional, 1912

Ibidem, sessão de $1^{\circ}$ de agosto de 1839

Ibidem, sessão de 2 de setembro de 1839 .

20

ANAIS DA CÂMARA DOS DEPUTADOS, sessão de 10 de junho de 1839. Rio de Janeiro, Tipografia Nacional, 1877

21

ANAIS DO SENADO DO IMPÉRIO, Op. Cit., sessão de 12 de maio de 1838.

Ibidem, sessão de 5 de setembro de 1839

23

Ibidem, sessão de 26 de julho de 1838.

24

ANAIS DO SENADO DO IMPÉRIO, Op. Cit., sessão de 2 de setembro de 1839. dividida em partidos e os partidos não admitem razão. Quem difere da sua opinião é estigmatizado. Assim, segundo a cor do partido, o Senado é regressivo e caminha para o absolutismo, ou progressivo e quer a República"17. Do lado do progresso, o senador maranhense Costa Ferreira, futuro Barão de Pindaré, pregava a necessidade de "observar a conduta dos ministros, ver se eles seguem o regresso ou o progresso, para se lhes negar ou conceder confiança"18. Seu colega de oposição, o senador paulista Nicolau Vergueiro, qualificava os dois lados políticos como representativos de tendências opostas do processo histórico. Se o "sistema do progresso" era o defensor "dos interesses públicos" e "do bem do país", o "sistema de regresso" seria aquele "das transações, cabalas e patronato" 19.

Na Câmara dos Deputados, era o mineiro Teófilo Otoni quem denunciava com mais acrimônia o caráter supostamente reacionário do regressismo: "Não se contentam os nobres deputados em querer parar em 1834 [ano do Ato Adicional]; quer se regressar de 1824 para trás", ou seja, para 0 absolutismo.$^{20}$ Esta não era, todavia, a opinião do principal chefe regressista, o senador mineiro Bernardo Pereira de Vasconcelos, ministro da Justiça e do Império, para quem o movimento por ele encabeçado era o portador do "verdadeiro progresso". Ele parecia mesmo não fazer questão de nomes: "Se o nome [regresso] é mau, se o nome é odioso, não popular, não duvidaremos abandoná-lo, chamando-o 'progresso'"'21. Na Câmara dos Deputados, o mineiro Cônego Marinho, velho partidário do "progresso" se queixava da inovação semântica introduzida por Vasconcelos:

Se se entendia por regresso um melhoramento razoável, para que se mudou o nome com que o pais estava acostumado que era regresso? Algumas leis não estão ao nivel da civilização do país, é preciso corrigi-las; mas, a isto, chamo eu um verdadeiro progresso. Para que se foi buscar uma palavra nova assustadora, que acarretou sustos muito reais? ${ }^{22}$

Também o líder da oposição ao regresso, o deputado Limpo de Abreu, chamava atenção para a contradição em que incorriam os regressistas: protestavam "contra inovações mal pensadas", mas queriam inovar novamente, mudando as instituições existentes, fato que tornava os liberais os verdadeiros defensores das instituições. A confusão se tornava patente, indagando Limpo a Vasconcelos onde ele próprio estava, se "no regresso ou no progresso"23.Já para o senador cearense Lopes Gama, essa discussão sobre progresso e regresso era de grande inutilidade:

Progresso e regresso designam uma política de nova invenção, política que alguns membros da câmara têm combatido ou defendido, sem que disto resultasse ao povo proveito algum. 0 que o povo quer é que se ocupem do seu bem, que se restabeleça a ordem e a tranquilidade. ${ }^{24}$

\section{A filosofia política do regresso: a bula das circunstâncias ou o realismo político.}

No final da década de 1830, Bernardo Pereira de Vasconcelos consagrava a excelência da monarquia constitucional como regime político. Tratavase de um regime de equilibrio entre a ordem representada pela Coroa, e a liberdade, pelo governo representativo:

Eu reduzia todas as minhas ideias a três palavras: Deus, trono e liberdade. Eis o fim que eu procuro atingir. Uma das máximas de que eu estou inteiramente convencido é que não pode haver trono e liberdade sem que um não absorva o outro, que 0 
trono não esmague a liberdade, e que a liberdade não esmague o trono. Até porque, de ordinário, ela desaparece sempre com ele. ${ }^{25}$

A perseguição do equilíbrio próprio à monarquia constitucional não estava, porém, isenta de dificuldades para Vasconcelos. Embora houvesse 0 progresso para a liberdade e para a democracia no curso da história, essa marcha estava longe de descrever um movimento retilíneo. A história do governo constitucional representativo demonstrava o quanto nele a estabilidade era difícil. Os combates entre estas paixões humanas sempre punham em perigo, por seus excessos, um dos elementos de que o equilibrio da monarquia constitucional carecia: ordem demasiada ameaçava restaurar o despotismo, ao passo que liberdade excessiva acenava com a anarquia: "Quando eu vejo um poder medonho que ameaça a liberdade, vou oferecer-Ihe o meu fraco apoio, a fim de ver restabelecido o equilibrio. Se é o trono que sustenta a liberdade, vou oferecer-Ihe o meu fraco, mas franco e leal"26. 0 dever do estadista estava, portanto, em lutar por aquele equilibrio: a liberdade com a autoridade, o progresso com a ordem, a democracia com a monarquia. Mas o tempo presente apresentava ao estadista desafios inéditos. Viviamos num tempo em que os homens se encontravam cada vez mais afastados e inimizados por interesses contrários. A civilização moderna diversificava "ao infinito os sentimentos, as naturezas, as necessidades", já não sendo "fácil achar dois homens com os mesmos sentimentos, ainda sobre as coisas mais necessárias"27. 0 presente era um "tempo de egoísmo", "em que os homens não estendem as suas vistas além de si próprios ou de sua família"28. Ademais, a existência humana era marcada atravessada pelo desconhecido: "Vagamos sempre em um mar de incertezas e flutuações" 29.

Diante desse quadro, o estadista não tinha opção senão deixar-se orientar conforme as circunstâncias, ou seja, as contingências e os constrangimentos do meio e do tempo: "Nos governos representativos, bem que sejam os mais perfeitos, não se faz sempre quanto é necessário, mas sim quanto o permitem as circunstâncias", afirmava Vasconcelos..$^{30} 0$ estadista precisava adaptar e modificar suas ideias conforme as necessidades impostas por aquelas circunstâncias: "Os perigos da sociedade variam; o vento das tempestades nem sempre é o mesmo: como há de o político, cego e imutável, servir no seu país?". Era preciso mudar a direção da ação política, sempre que se tratasse de "desviar-se de um caminho que tem reconhecido que conduz ao precipício"31. Equivocavam-se, portanto, aqueles para quem a política seria uma ciência tão certa quanto a geometria. Relevando ainda do domínio do experimental, do histórico, do contingente, ela era na verdade a mais atrasada das ciências: " 0 espírito que está habituado ao estudo das ciências exatas quer encontrar a verdade absoluta e resultados positivos em toda a parte, mas os fatos e os acontecimentos o desmentem sempre" ${ }^{\prime 2}$. Porque os fatos e acontecimentos da vida humana a todo o momento desmentiam a "verdade absoluta" buscada pelos homens de ciências, Vasconcelos revelava-se cético sobre a possibilidade de que em algum dia a política pudesse tornar-se de fato uma ciência:

\footnotetext{
Se a política tivesse regras certas e de uma aplicação invariável, seria, sem dúvida, uma ciência ao alcance de todos; mas a dificuldade de aplicar as regras, de modificá-las, de acomodá-las ao estado social, é o que torna a ciência política a mais difícil de todas as ciências e que faz com que todos os publicistas de boa-fé reconheçam que é a que está mais na sua infância. ${ }^{33}$
} 
36

Ibidem, sessão de 16 de julho de 1839.

37

Ibidem, sessão de 25 de maio de 1839.

38

Ibidem, sessão de 28 de maio de 1839.

39

Ibidem, sessão de 17 de outubro de 1839 .

40

Ibidem, sessão de 12 de junho de 1839

41

Ibidem, sessão de 13 de janeiro de 1845.

ANAIS DO SENADO DO IMPÉRIO. Loc. Cit.

44

Ibidem, sessão de 23 de julho de 1839.
Por essas razões, Vasconcelos confessava não ter "muita afeição à metafísica" ${ }^{34}$. Ele não acreditava em uma política orientada exclusivamente pela moral e menos ainda que ela bastasse para manter os homens coesos e subordinados. Embora reconhecesse "o quanto a moral influi no homem", especialmente para "nossas afeições domésticas e mundanas", ela raramente bastaria para organizar um pais. ${ }^{35}$ Vasconcelos também questionava os fundamentos do liberalismo de orientação ideológica "republicana", especialmente aquele de matriz kantiana. Para ele, todos os homens eram guiados por suas prevenções e seus preconceitos: "Às vezes previno-me a respeito das coisas e das pessoas em questão, mas nunca pensei que houvesse pessoas tão felizes no mundo que estivessem isentas das prevenções" ${ }^{\prime \prime}$. Neste sentido, Vasconcelos era taxativo ao afirmar: "Em política e moral, não há princípios absolutos"37. Ele reconhecia haver "algumas regras de moral que não admitem exceção, por exemplo, o temor de Deus"38. Mas eram exceções. Por isso, declarava sem rebuços: "Eu não sou, como já por vezes tenho declarado, advogado de proposições gerais". Além de falsos e desagradáveis, os princípios absolutos só serviam "para quem quiser fazer oposição"39. Também não seria possivel, senão com grande perigo, admitir a "pretensão de formar todos os homens pelo mesmo modelo", segundo principios gerais e abstratos. ${ }^{40}$

A expressão "bula das circunstâncias" tornou-se de uso corrente naqueles anos, para designar o realismo de Vasconcelos e sua crença na necessidade de deixar de lado em certas ocasiões os preceitos da moral e da lei e orientar-se conforme a razão de Estado. Seu amigo e colega Honório Hermeto Carneiro Leão narraria da tribuna um caso paradigmático. No começo da Regência, às voltas com a repressão de uma rebelião, Vasconcelos teria ordenado a remoção de um pároco, embora inamovível pelo direito canônico, invocando uma determinada bula que Ihe daria aquela prerrogativa. Anos depois, o político mineiro teria justificado a medida alegando ter sido "movido por uma necessidade momentânea, para evitar um mal maior; e quando se lhe lembrou a bula por ele citada, respondeu: 'A bula que me guiou foi a bula das circunstâncias'"'41. Esta expressão traduzia, portanto, a crença de que, devido à natureza cambiante da vida e da política, o estadista precisava variar os seus princípios conforme o exigissem as circunstâncias: "Dizia eu que tudo muda em torno do homem, e que por isso não é de estranhar que ele também modifique suas ideias. É exigir muito da humanidade impor-lhe a obrigação de pensar sempre do mesmo modo e não modificar os seus pensamentos". Além disso, o homem também variava conforme diversos fatores ao longo da vida. "Tudo muda nesse vale de lágrimas; muda-se com a idade, com as moléstias, com os estudos, com os trabalhos, etc." ${ }^{42}$. Por isso, em matéria política e moral, a imutabilidade não era virtude:

Não tenho orgulho de ser imutável e parece-me que é muito próprio mudar de opinião, quando se reconhece o erro; ao menos, tenho uma inteligência de cera (permita-me a expressão) para a verdade, e seja ela de bronze para o erro. Quando se me apresenta a verdade, não posso resistir-Ihe, embora estivesse eu ligado a este ou àquele partido; se aparece a verdade, aceito-a e obedeço-Ihe. ${ }^{43}$

A Vasconcelos não parecia possivel que um homem de boa-fé pudesse "professar sempre as mesmas ideias, ainda que as reconheça errôneas" 4 . 0 estadista tinha o dever de rever suas ideias e principios conforme as circunstâncias, adaptando-se a elas, ainda que chefe de partido. Não se 
46

Ibidem, sessão de 9 de agosto de 1839 .

Ibidem, sessão de 24 de maio de 1839. tratava de mudar de opinião ou ideias por mudar, por inconstância, por fraqueza, de caráter, mas pelo amor da verdade:

0 que é condenável é mudar de opinião sem razão suficiente. Este caráter é muito fraco. Mas, quando se muda por amor dos princípios, pode taxar-se tal mudança? Eu faço consistir a firmeza do caráter em armar os princípios por causa da verdade. V. Exa. há de concordar que esta definição é muito exata: amar os princípios, não por eles, mas por causa da verdade. Quando, pois, a verdade não pode ser bem atingida, sem alteração ou combinação dos princípios, é de razão obedecer a essa voz imperiosa da rainha do mundo, abraça-la e executar os seus ditames. Ora, sendo este o conceito que eu formo de um caráter firme, bem vê V. Exa. que só quem não for amigo da verdade rejeitará sempre toda e qualquer modificação em seus princípios.

\section{0 diagnóstico regressista da desordem e a crítica do progresso enquanto espírito de inovação.}

A guerra civil, que grassava no Rio Grande do Sul, no Maranhão, no Pará e na Bahia, era o contexto em que atuavam os políticos brasileiros da segunda metade da década de 1830. Para Vasconcelos, "a guerra civil está devorando uma não pequena parte do Império do Brasil"45. A seu ver, os conflitos intestinos resultavam da incompetência dos liberais em estabelecerem uma ordem que garantisse a obediência dos cidadãos: "A insubordinação é a ordem do dia"46. A transição para o liberalismo, entendido como sistema em que o Estado deixava de dirigir a sociedade para ser dirigido por ela, teria sido brusca demais. Esta era a causa eficiente da desordem: "0 pais que faz uma transição como nós fizemos não pode deixar de estar agitado. E que transição? Do estado de absolutismo para o das instituições as mais liberais que se conhecem. Eis o elemento de desordem; toda a legislação tem ido de acordo com este sistema [do progresso]; não temos caminhado pouco a pouco, como era minha opinião (e este é um dos dogmas do regresso)" 47 . Essa crítica ao "progresso" dos anos anteriores era acompanhada de uma sensação dupla: a de uma aceleração extraordinária do tempo, desde a revolução liberal de 1821, e a da incapacidade demonstrada pela sociedade brasileira de digerir tanta mudança em tão curto período:

\footnotetext{
A história das revoluções e das comoções intestinas, que tantos males têm feito ao Brasil, não datam de 7 de abril de 1831: o Brasil está inquieto desde 1821, desde que se proclamou o sistema constitucional. Desde então apareceu um espírito de agitação, manifestaram-se pretensões exageradas. Até então a obediência era geral e passiva; de então em diante entendeu-se que era até virtude desobedecer, não cumprindo as ordens de seus superiores. Desde 1821, o pais tem estado em grande agitação, com a diferença de que em algumas épocas tem sido maior e em outras, menor. 0 espírito de oposição foi apoderando-se das massas, e se, num governo constitucional representativo, ainda que bem montado e cimentado por longa duração, nem sempre as resistências produzem bons efeitos, como não encontrará o país essa resistência, não tendo ainda nós o prazer de ver consolidadas as nossas instituições? Durante o reinado do Sr. D. Pedro I, houve muitas comoções. Verdade é que em alguns pontos a tranquilidade parecia estar consolidada, mas só o estava aparentemente: a anarquia surda reinava nos espíritos. Eu não falo da anarquia das ruas, das praças, do cacete e do punhal; penso que ano houve em que tal anarquia desapareceu do país. 0 movimento de 7 de abril de 1831 veio aumentar essa desordem, esse mal moral de que estavam eivados os espíritos. Às comoções sucederam sedições; às sedições, rebeliões; e assim tem caminhado o Brasil até a época em que vivemos. ${ }^{48}$
}

Este também era o diagnóstico de três senadores do Império que acumulavam suas funções com aquelas de magistrados da mais elevada 
49

Ibidem, sessão de 28 de setembro de 1839.

50

Ibidem, sessão de 13 de maio de 1839.

51

Ibidem, sessão de 18 de maio de 1839.

52

Ibidem, sessão de 6 de junho de 1839 .
Corte do país, o Supremo Tribunal de Justiça: os baianos Francisco Carneiro de Campos e Cassiano Melo Matos, e o cearense Caetano Maria Lopes Gama, futuro Visconde de Maranguape. Os altos magistrados haviam sido largamente desprestigiados com as reformas liberais dos anos anteriores que, realizadas em boa parte contra a magistratura, buscara enfraquecê-la no nivel local. Para o senador Melo Matos, a anarquia datava "talvez em grande parte da revolução de 7 de abril, e tem progredido daí em diante". As principais causas da desordem eram o déficit público, a falta de harmonia entre os poderes e "a imoralidade geral". Ele concluía, como Vasconcelos, que a fonte dos males residia na "tendência direta para revoluções, da tendência direta para a desobediência da lei e às autoridades constituídas" 49 .

Para os senadores regressistas, a desordem tinha, ademais, uma causa intelectual: a tentativa precipitada de se promover o "progresso" - isto é, a liberação dos interesses fragmentários da sociedade em detrimento da ordem pública. "Progresso", no discurso de Vasconcelos, significava "movimento" e "inovação": o "espírito de inovação" era "um espírito de progresso" ${ }^{150}$. Essa promoção se fizera pela adoção, por parte dos liberais, das ideias e instituições de paises cêntricos como os Estados Unidos e a Inglaterra, com completo desdém pelas circunstâncias do Brasil. Esse "progresso" se revelara um verdadeiro retrocesso, porque desorganizara as bases sobre as quais até então se assentavam a ordem e a união nacional, sem organizar outras que a assegurassem. A mesma crítica transparecia na declaração de Lopes Gama: "A ordem civil ressente-se dos efeitos das novas leis com que quisemos substituir a antiga legislação, e que em grande parte não estavam em harmonia com as nossas instituições, nem com o estado de civilização e desenvolvimento em que nos achamos, atualmente. Transplantamos para o Brasil legislações exóticas acomodadas a outros costumes e condições sociais, e ficamos em pior estado do que estávamos"51. A passagem abaixo, na qual Vasconcelos discorria sobre os problemas decorrentes da introdução do júri no Brasil, também ilustra a forma por que, no seu pensamento, ele articulava a sensação de aceleração do tempo político aos efeitos desagregadores da introdução de instituições estrangeiras, descompassadas com a sociedade brasileira:

Fizemos uma grande obra estabelecendo os jurados. Julgamos que tínhamos felicitado o nosso país só porque ouviamos que na Inglaterra havia, por exemplo, um bom juizo de jurados; e, sem procurarmos indagar as causas que faziam com que aquele juizo produzisse a força e a prosperidade da Inglaterra, entendemos que devíamos naturalizá-lo no Brasil e por isso todos nós temos queixado das impunidades. [...]. Como se postergou a teoria do regresso, como nos lançamos de um só pulo do juízo inquisitorial para a publicidade do processo do júri, pioramos muito a nossa jurisprudência criminal. Os ânimos não estavam dispostos para tal mudança, e o que tem resultado é que muitos antigos defensores do progresso querem hoje recuar para o estado anterior. ${ }^{52}$

Para Vasconcelos, o ponto alto do desastrado intento de promoção do progresso pelos liberais teria sido a reforma constitucional, por que 0 governo geral abdicara nas províncias os poderes de polícia e judiciários na primeira instância, sem distinguir de modo claro as atribuições gerais das provinciais. Este era um caso evidente de má cópia das instituições norte-americanas, em que aquela distinção se fizera de modo a não deixar dúvidas. Além disso, ao contrário da sociedade estadunidense, a brasileira não estava suficientemente preparada para o federalismo, compreendido 
Ibidem, sessão de 29 de maio de 1839.

54

Ibidem, sessão de 13 de junho de 1839.

55

VASCONCELOS, Bernardo Pereira de. Manifesto Político e Declaração de Princípios. Brasília: Senado Federal, 1978. p.24.

56

ANAIS DA CÂMARA DOS DEPUTADOS. Op. Cit., sessão de 17 de agosto de 1838 .

57

ANAIS DO SENADO DO IMPÉRIO. Op. Cit., sessão de 6 de junho de 1839.

58

ANAIS DO SENADO DO IMPÉRIO. LOC. Cit. como um sistema de autogestão capaz de dispensar a tutela da União. Vastas extensões territoriais do pais encontravam-se fora do alcance do governo e das leis nacionais, estando suas populações nas mãos de selvagens, criminosos e bárbaros donos de terras. Estender a autoridade civilizadora do Estado sobre o conjunto do território nacional era logicamente um pressuposto à eventual autonomização das províncias. Por isso, Vasconcelos entendia que aquele não era o tempo de dispersar, e sim de concentrar o poder. 0 federalismo só seria benéfico ao Brasil "depois que a civilização tiver chegado a tal ponto que se achem todos os meios de governar em toda a parte" ${ }^{15}$. Também Lopes Gama achava que o estado calamitoso do país derivava da cópia defeituosa do federalismo: "Nós não podíamos tomar por modelo as instituições de um país que tem uma composição mui diversa do nosso" ${ }^{54}$. A experiência desastrosa das reformas liberais levou então Vasconcelos a elaborar aquilo que ele denominaria "o sistema do regresso". É nesse contexto que ele proferiu a célebre justificativa de sua virada conservadora:

Fui liberal; então a liberdade era nova no país, estava nas aspirações de todos, mas não nas leis; o poder era tudo: fui liberal. Hoje, porém, é diverso o aspecto da sociedade; os princípios democráticos tudo ganharam e muito comprometeram; a sociedade, que então corria risco pelo poder, corre agora risco pela desorganização e pela anarquia. Como então quis, quero hoje servi-la, quero salvá-la: e por isso sou regressista. ${ }^{55}$

\section{0 remédio aos males da desordem: o "sistema do regresso".}

0 regresso significava, para Vasconcelos, a aplicação da bula das circunstâncias (o realismo político) à política brasileira, como resposta aos problemas decorrentes da transposição acrítica das teorias cêntricas (norte-americanas e inglesas) para o contexto brasileiro. A erosão da autoridade do Estado, a subversão do princípio da obediência e a dissolução da comunidade política eram os resultados de uma engenharia institucional equivocada, calcada na crença de uma universalidade cultural e de uma relativa sincronia entre centro (Atlântico Norte) e periferia (Brasil). Respeitando o estado social da Nação, o regresso haveria de corrigir os efeitos daquele excesso de liberalismo, extinguindo ou adaptando as inovações introduzidas: "Eu tenho concorrido para dotar o meu país com as instituições as mais liberais conhecidas no mundo, mas nem por isso me considero dispensado de separar de algumas dessas instituições alguma liga anárquica que nelas se tenha introduzido, nem de pedir às circunstâncias meios de restringi-las, quando o exige o bem do Estado" ${ }^{\prime 6}$. As teorias políticas de países reputados modelares pela classe política brasileira tinham sido feitas sem antes questionar a sua compatibilidade com as necessidades locais:

\footnotetext{
Nós não temos sondado as necessidades, para o dotarmos das instituições de que ele precisa. [...] Lemos uma linda teoria; diz um outro que a esta teoria deve tal pais a sua prosperidade, fortuna e glória; queremos logo naturalizar no nosso país essa instituição; andamos sempre aos saltos e daí vem que não poucas vezes temos baqueado. ${ }^{57}$
}

0 sistema do regresso passava, em primeiro lugar, pela crítica do caráter metafísico e universalista do reformismo. Os liberais brasileiros se orientavam por princípios metafísicos, de um cosmopolitismo exagerado, que não tinham "nem o abono da ciência nem a sanção do século"58. Era com essa concepção que, a 9 de agosto de 1839,Vasconcelos criticava o senador cearense José Martiniano de Alencar, um dos principais chefes do 
ANAIS DA CÂMARA DOS DEPUTADOS. Op. Cit., sessão de 17 de agosto de 1838 .

61

Ibidem, sessão de 12 de maio de 1838 .

62

ANAIS DO SENADO DO IMPÉRIO. Op. Cit., sessão de 23 de maio de 1844 .

63

ANAIS DA CÂMARA DOS DEPUTADOS. 0p. Cit., sessão de 5 de julho de 1838.

64

Ibidem, sessão de 11 de setembro de 1838 . "progresso": parecia-Ihe que colega guiava-se conforme uma "ideia de perfeição, pela qual julga que devem ser feitas as instituições, sem nenhuma atenção às circunstâncias do país; quer formar os homens para as instituições e não as instituições para os homens" ${ }^{159}$. Como critério de triagem das ideias estrangeiras, Vasconcelos e seus partidários advogavam, conforme referido, a adoção da categoria de circunstância, que aludia à consideração de duas variáveis: a primeira, sociológica, dizia respeito ao estado sociocultural do país; a segunda, temporal, dizia respeito à etapa histórica por ele atravessada no processo de civilização: "Convido os nobres deputados a contestar estes princípios, a mostrar que a política, que a ciência do governo, proibe que se acomodem as leis às necessidades do pais, às suas circunstâncias" 60.0 regresso significava interromper também o processo de importação acrítica das instituições de outros paises.

\begin{abstract}
0 sistema do regresso, senhores, consiste em não adotar como opinião pública qualquer boato que um ou outro foliculário apregoa como tal. 0 sistema do regresso ensina a avaliar as medidas que se pretendem adotar para o bem do pais e submetêlas à discussão, não do partido republicano ou deste ou daquele outro - porque discussões entre partidos são infrutuosas -, mas sim em suscitar a discussão entre as diversas opiniões, os diversos interesses, para atinar com a verdadeira opinião do pais. ${ }^{61}$
\end{abstract}

Em segundo lugar, o sistema do regresso relativizava o caráter eurocêntrico e absoluto por que os liberais interpretavam a filosofia da história como progresso da liberdade, levando-os a atacar o Estado em proveito da sociedade civil. As circunstâncias impunham reconhecer que, uma vez que a monarquia constitucional dependia do equilibrio entre ordem e liberdade, os males políticos podiam provir da direita, pelo excesso de autoridade contra a liberdade, mas também da esquerda, pelo excesso de liberdade que erodisse a ordem. Tudo dependia do estado social do país e de seu momento histórico. 0 importante era ajustar a ambos as instituições, fórmula que prevenia o despotismo de um lado e anarquia do outro: "Se as revoluções procedem da desarmonia entre as ideias e as instituições dos povos, é evidente que todas as vezes que se puderem harmonizar as instituições às ideias, desparecem as revoluções. A sabedoria do governo, a sua previdência, está em saber atalhar as revoluções, satisfazendo as necessidades públicas" 62 . 0 Estado deveria promover um ou outro, conforme as famosas circunstâncias.

\footnotetext{
0 governo deve aplicar-se, deve esmerar-se em satisfazer todas as necessidades públicas, e que, se se apresentam circunstâncias que exigem do governo providências, que sacrifiquem parte da ordem social à segurança pessoal, ele deve cumprir o seu dever; e, se pelo contrário, aparecem circunstâncias que exigem (...) que a ordem social peça empréstimo, ainda que por curto prazo, à segurança individual, o governo não deve recuar, ainda que resulte impopularidade; deve pedir ao corpo legislativo o que julga necessário. ${ }^{63}$
}

Naquele momento de concentrar esforços para a organização do Estado brasileiro, dever-se-ia confiar mais na força da autoridade do que na da sociedade: "0 primeiro dever de um governo é a conservação do país", declarava Vasconcelos. ${ }^{64}$ Por conservação do país, os regressistas entendiam a unidade territorial do Império, a monarquia constitucional e, com ela, o primado da lei, contra o poder pessoal dos eventuais caudilhos que inevitavelmente prevaleceriam no regime formalmente republicano. 0 deputado Carneiro Leão, aliado regressista de Vasconcelos, repetia na Câmara que "a maior desonra que pode cair sobre o Brasil é dilacerar-se, dividir-se, 
ANAIS DO SENADO DO IMPÉRIO. Op. Cit., sessão de 26 de setembro de 1839 .

67

Ibidem, sessão de 16 de maio de 1839.

68

ANAIS DO SENADO DO IMPÉRIO. Loc. Cit.

69

ANAIS DO SENADO DO IMPÉRIO. Loc. Cit.

70

ANAIS DA CÂMARA DOS DEPUTADOS. Op. Cit., sessão de 2 de maio de 1838 .

71

ANAIS DO SENADO DO IMPÉRIO. Op. Cit., sessão de 25 de maio de 1839 .

72

Ibidem, sessão de 21 de outubro de 1839 reconhecer como estado independente a província do Rio Grande do Sul; e assim virem a aparecer régulos e ditadores, que destruam o único sistema que (...) pode fazer a felicidade do pais"65. Cerca de um mês depois, o também já referido senador Melo Matos sustentaria assertivas semelhantes:

\begin{abstract}
Os meus princípios, no estado atual do Brasil - em que não conheço senão um espírito revolucionário - são sustentar o governo, porque é preciso conservar um elemento de ordem e de força que possa abafar as ideias desregradas e destruidoras do bem-estar da sociedade; e neste elemento de ordem e força eu não o conheço senão na ação do governo, porque governo não quer dizer senão força e ordem, e por consequência tenho trabalhado e trabalharei para a sustentação do governo. ${ }^{66}$
\end{abstract}

Eram dois os principais meios por que, na chefia do governo, Vasconcelos buscava apoio para o programa regressista. 0 primeiro era o chamado "governo das transações" ou dos compromissos. Num mundo em que o princípio hierárquico absoluto se desvanecera e, com ele, a possibilidade de um consenso imposto do alto, o exercício do governo só poderia chegar a bom termo caso seus estadistas se empenhassem em uma contínua negociação com os representantes dos demais interesses sociais e econômicos: "Em um governo livre, não pode haver obediência, regularidade, ordem, senão por meio da transação"67. Para Vasconcelos, era preciso que "um dê ao outro um pouco, e o outro, outro pouco, a fim de que possa haver unidade de pensamento e unidade no regime"68. Por isso, o regime das transações e dos compromissos políticos era por ele considerado "da essência de todo o governo livre"69. 0 segundo meio de obtenção de apoio para o programa regressista era o "medo", entendido como a ameaça de coação legal aos recalcitrantes a fim de fazer valer as ordens da autoridade pública: "Não pode haver boa política sem respeito. Como estou na convicção de que nada se respeita quando nada se teme, por isso julgo que o governo deve ter força, e deve empregar a força, em todos os casos. Em todas as questões morais se vê sempre que o princípio dominante é o respeito e o medo"70. 0 temor era "tão necessário à espécie humana como ar à vida do indivíduo; ele regula todas as ações, tanto dos cidadãos, como entre o cidadão e o príncipe; até as nossas relações com a divindade; e, com efeito, muitas vezes deixamos de praticar uma ação pelo receio dos males a ela inerentes"71. No governo representativo, o medo não era a mola do despotismo, mas o meio de, por meio de prêmios e punições, restabelecer o prestígio do Estado e angariar a obediência. Daí que ele entrasse nos cálculos do estadista como elemento de administração: "Nenhum governo pode existir sem o direito de se impor; ninguém pode justamente pretender os cômodos sociais, sem sofrer os incômodos sociais"72.

\section{Parar, recuar e ralentar: o regresso enquanto modulação das temporalidades}

De que maneira um movimento político denominado regresso e dotado das características definidas se articulava teoricamente com a filosofia da história, entendida como progresso indefinido da liberdade? Para examinar a questão, é preciso verificar os sentidos semânticos do conceito de regresso e de seu oposto - progresso -, disponíveis na leitura da época. Em 1831, o principal dicionário em uso no mundo luso-brasileiro, o Moraes, definia o progresso como "adiantamento em proveito, ou efeito", citando como exemplo "fazer progressos nas artes, ciências". Já o regresso era definido pelo dicionário como "tornada atrás, ao lugar donde saiu quem regres- 
73

MORAES E SILVA, Antônio de. Dicionário da Língua Portuguesa. $3^{\text {a }}$ edição. Lisboa: Tipografia Lacerdina, 1831. p.606.

74

ANAIS DA CÂMARA DOS DEPUTADOS. Op. Cit., sessão de 12 de maio de 1838 .

75

ANAIS DO SENADO DO IMPÉRIO. Op. Cit., sessão de 29 de maio de 1839 .

76

ANAIS DO SENADO DO IMPÉRIO. Loc. Cit.

77

Ibidem, sessão de 5 de setembro de 1839.

78

ANAIS DA CÃMARA DOS DEPUTADOS. 0p. Cit., sessão de 11 de junho de 1839.

79

ANAIS DO SENADO DO IMPÉRIO. Op. Cit., sessão de 6 de junho de 1839. sa". Embora o conceito de regresso fosse definido apenas espacialmente, os exemplos eram todos de gênero temporal: "0 tempo passado não tem regresso"; "o tempo que não tem regresso", isto é, "o que é passado não volta a tornar" ${ }^{173}$. Entretanto, os regressistas ignoravam estas definições, demonstrando acreditar - metaforicamente, pelo menos - na possibilidade de se modular o tempo brasileiro por um ato de vontade política. A tentativa de modernização do país pela engenharia institucional, depois da queda do Antigo Regime e da declaração da independência, havia sido feita com precipitação, sem levar em conta a necessidade que a sociedade tinha de preparar-se para todas as mudanças. 0 conceito de regresso está associado tanto à ideia de fazer o tempo, que acelerava de forma vertiginosa, retroagir, pará-lo ou, pelo menos, desacelerá-lo. A sensação de aceleração era transmitida por metáforas espaciais de movimento: "de um salto", "de um só pulo", "precipitação". As demais articulações da temporalização experimentada pela política também eram apresentadas por meio de metáforas espaciais.

Parar o tempo. A 12 de maio de 1838, na Câmara, Vasconcelos ensaiou pela primeira vez explicar em público o significado do regresso "desta palavra, deste sistema, que eu considero o verdadeiro progresso". Até recentemente, se havia entendido que "o liberalismo consistia em derrubar tudo quanto nos legaram os nossos antepassados", e contra "esse prurido de inovar" ele empregara "a palavra regresso como sinônimo de recurso. ${ }^{74} \mathrm{~A}$ crença na possibilidade de interromper o curso do tempo histórico transparece na declaração de Vasconcelos segundo a qual ele pretendera "parar o carro revolucionário; atirei-me diante dele; sofri e tenho sofrido, porque quem se atira diante do carro revolucionário de ordinário sempre sofre". Foi então que, segundo o senador mineiro, "uns julgaram que era ocasião de caminhar, e caminharam; outros julgaram que se devia fazer alto"75. Alguns dias depois, para descrever o sentido do regresso enquanto congelador do tempo político, ele voltava às metáforas espaciais: "A experiência me convenceu de que, continuando da mesma forma, o paradeiro seria o abismo. Mudei; tenho seguido o que a razão e a observação me têm aconselhado como mais apropriado a fazer à prosperidade do pais". Na prática, parar o tempo significava opor-se a qualquer nova alteração constitucional: o regresso era "a religiosa observância da Constituição"76. 0 líder do regresso na Câmara dos Deputados, Carneiro Leão, repetia: "A nossa única tábua de salvação é conservar intacta a Constituição"77.

Recuar o tempo. 0 regresso passava pela adoção de ações destinadas a corrigir a disjunção decorrente da diversidade de temporalidades e de cultura política entre os países centrais reputados modelares e o Brasil. Este é o sentido que o deputado Moura Magalhães parece lhe ter emprestado: "0 que é regresso? Se o nobre deputado entende a doutrina do regresso voltar ao absolutismo, eu digo que o abomino - vade retro -, mas se entende regresso corrigir os erros que existem nas nossas instituições, pôr em harmonia com as necessidades públicas as atribuições políticas dos poderes, a fim de evitar perigosos conflitos que dão grandes abalos na máquina social, digo que sou regressista"78. A possibilidade de retroceder 0 tempo para o período anterior às reformas liberais e recuperar o controle do país por parte do governo transparecia em declarações de Vasconcelos: "Eu quero a ressurreição do que é bom. Se, voltando atrás, podemos encontrar com a liberdade, com a glória do nosso país, eu assim mesmo trôpego correrei, voarei em busca de tão grande bem"79. Essa concepção 
80

ANAIS DA CÂMARA DOS DEPUTADOS. Op. Cit., sessão de 18 de maio de 1838.

81

ANAIS DO SENADO DO IMPÉRIO. Op. Cit., sessão de 25 de maio de 1839 .

82

A referência favorável aos unionistas estadunidenses (federalistas) era acompanhada de outra, desfavorável aos liberais radicais estadunidenses. Jefferson era por Vasconcelos referido como autoridade a quem não era "muito afeiçoado, talvez pelo meu sistema de regresso". ANAIS DO SENADO DO IMPÉRIO. Loc. Cit.

83

Ibidem, sessão de 8 de junho de 1839.

84

Ibidem, sessão de 4 de junho de 1840.

85

lbidem, sessão de 25 de outubro de 1839 transparece também no discurso do deputado paulista Antônio Carlos de Andrada Machado: "Regresso quer dizer marcha para trás, isto é, percorrer um espaço que antes já tinha sido percorrido". Não era nenhum desdouro retornar por um caminho já percorrido, quando deparávamos com mil dificuldades ao longo dele:

Todas as sociedades, todos os homens caminham para a felicidade [...]; se o caminho que seguimos é cheio de espinhos, de pântanos; enfim, de mil empecilhos, não é infâmia, não é desonra retroceder para seguirmos outro caminho melhor, que nos conduza ao mesmo que desejamos, mas com menos incômodos e riscos. ${ }^{80}$

Ralentar o tempo. Por fim, surge a imagem do tempo domado, ralentado. Citando o federalista Washington, Vasconcelos afirmava que um dos "dogmas do regresso" estava em caminhar "com pé lento, mas firme". Combatia-se, desta forma, o "espírito de inovação"81. A "sublime teoria do regresso" ensinava os estadistas "a caminhar no aperfeiçoamento das instituições do país com pé lento, mas firme. Não quero dar saltos no abismo, para depois recuar e espavorido ir cair em outro abismo, e recuar até os tempos do sistema colonial|"82. 0 senador mineiro Marquês de Barbacena endossava: embora se devesse admitir "o princípio do melhoramento progressivo da espécie humana", o estadista deveria ser avesso a "inovações precipitadas" 83 . Noutra ocasião, Vasconcelos dava um exemplo prático de aplicação do "sistema do regresso", referindo-se ao necessário reexame da legislação criminal:

Segundo este meu sistema, que se tem qualificado de regresso, vou sempre acomodando toda a legislação no criminal debaixo de uma só espécie; só faço distinção quando as circunstâncias do país exigem a punição de certos delitos com mais prontidão, com mais severidade; mas, quando as circunstâncias mudam, e os delitos se tornam menos frequentes, quando se não padecem tantos males como quando eram mais severamente punidos, então se deve deixar-se à legislação ordinária a sua punição; deve de algum modo tornar-se menos severa a punição; e por isso é necessário que a legislação criminal acompanhe a legislação do pais. ${ }^{84}$

0 senador e magistrado baiano Carneiro de Campos também entendia que cada país tinha as suas peculiaridades e por isso as "novidades" dos países cêntricos só poderiam ser introduzidas no Brasil com toda a cautela e paciência:

Cada país, senhores, tem seus costumes e suas leis, que são amoldadas às circunstâncias peculiares de cada pais. Nós já fizemos uma tentativa de seguir o exemplo do sistema inglês em matéria criminal, e não nos saimos muito bem; ao menos, muito se tem clamado contra isso, quando eu estou persuadido que a instituição dos jurados pode até ser considerada como um elemento de civilização do povo brasileiro; é bom que o povo se julgue a si, para se convencer mesmo da justiça. (...). Todas as coisas do mundo têm o seu noviciado; nós estamos nele, e por isso é preciso que tenhamos paciência, para que se arraigue entre nós esta instituição, que é muito saudável. ${ }^{85}$

Postos na oposição por Vasconcelos, os liberais ou progressistas do final da década de 1830 combatiam arduamente os argumentos regressistas. Ao se orientarem por uma ideologia de fundo republicano, cosmopolita e moralista, eles mostravam a distância que pretendiam guardar da orientação cética, nacionalista e utilitária, ou pragmática, dos regressistas. Seu principal chefe, o senador paulista Diogo Antônio Feijó, havia sido o 
FEIJÓ, Diogo Antônio.Cadernos de Filosofia. Introdução e notas de Miguel Reale. São Paulo: Grijalbo, 1967.

87

ANAIS DO SENADO DO IMPÉRIO. Op. Cit., sessão de 27 de maio de 1839 .

88

De acordo com Feijó, a filosofia moral kantiana faria reviver no homem "o sentimento de sua dignidade, pela nobreza de motivos que devem dirigir ações, e pelo fim elevado, a que destinou o autor da natureza. 0 sentimento inato da justiça o conduzirá a crer na necessidade de um juiz supremo, reto e imparcial; bem como de uma vida futura, onde postas em harmonia suas inclinações, tenha a virtude a necessária recompensa. Neste estudo, aprenderá o homem em detalhe seus direitos e seus deveres, e na teoria da felicidade saberá distinguir a falsa da verdadeira" (ANAIS DO SENADO DO IMPÉRIO. Op. Cit., sessão de 31 de maio de 1839).

89

ANAIS DO SENADO DO IMPÉRIO. Loc. Cit. 90

Ibidem, sessão de 29 de maio de 1839.

91

Ibidem, sessão de 24 de maio de 1839. Ao contrário do que se possa imaginar a primeira vista, a comparação de Vasconcelos com Mirabeau não tinha propósitos lisonjeiros, porque aludia ao fato de que, orador mais brilhante da Constituinte francesa, Mirabeau era também estipendiado pela Coroa. A comparação estabelecida por Costa Ferreira aludia assim ao oportunismo ou imoralidade dos atos de Vasconcelos.

92

ANAIS DA CÂMARA DOS DEPUTADOS. Op. Cit., sessão de 10 de junho de 1839.

93

ANAIS DO SENADO DO IMPÉRIO. Op. Cit., sessão de 18 de junho de 1839 .

Ibidem, sessão de 24 de maio de 1839.

95

Ibidem, sessão de 9 de agosto de 1839.

96

ANAIS DA CÂMARA DOS DEPUTADOS. Op. Cit., sessão de 4 de julho de 1838. A fim de obstarem à marcha irresistivel do movimento regressista, todos esses atores se acumpliciariam no Clube da Maioridade, destinado a pôr fim aos governos regenciais pela antecipação da declaração de maioridade do Imperador fixada na Constituição por meio de um golpe parlamentar (HÖRNER, Erik. Até os Limites da Política: a "revolução liberal" de 1842 em São Paulo e Minas Gerais. São Paulo: Alameda, 2014. p.96). Quando novamente apeados do poder pelos conservadores, em 1842, pegariam em armas nas províncias de São Paulo e de Minas Gerais para impedir a conclusão do processo de reformas previsto por Vasconcelos. Acabaram derrotados em definitivo na batalha de Santa Luzia. Dai o epiteto por que passariam a ser conhecidos: seriam, até o final do Império, os santa luzias, ou simplesmente luzias. principal introdutor no Brasil da filosofia de Kant ${ }^{86}$ e da tribuna parlamentar reiterava sua crença na existência de regras imutáveis, universais e eternas de moral política: "Há princípios a priori, anteriores aos fatos que os regem, e são estes o que constituem a ciência"87. Baseado neste "autor, para mim, muito judicioso" (Kant), ele apresentara um projeto de sistema educacional que levasse as crianças a "desenvolver a razão, para esta habilitar-se a compreender verdades que Ihe sirvam o resto da vida". Era assim do polo oposto ao do cético Vasconcelos que Feijó fazia da tribuna o elogio da metafísica como a "ciência das ciências, a ciência dos princípios", que levaria o homem a conhecer "o que é real e fenomenal; o que é objetivo e subjetivo, e colocando-o no mais alto das abstrações, Ihe entregará a chave dos conhecimentos humanos"88. Ele acreditava na objetividade do conhecimento moral, a partir do qual seria possivel desenvolver uma ação política baseada na verdade:

Pela aplicação da legislação natural ao estado social, [o homem] conhecerá os vícios e a imperfeição das diferentes constituições; porquanto o direito público se encarregará de mostrar a origem das sociedades legítimas, o seu verdadeiro fim, os meios de promover sua prosperidade e as diferentes formas dos governos, suas vantagens e inconvenientes; enfim, as garantias necessárias para preservar a sociedade do flagelo da anarquia ou do despotismo. ${ }^{89}$

Em nome do progresso moral, os liberais criticaram os regressistas por seu oportunismo e versatilidade. Feijó dirigia a Vasconcelos a crítica que Kant fizera a Hume: o chefe regressista Ihe parecia "um perfeito incrédulo em política"90. 0 senador Costa Ferreira também o acusava de ser uma "arteira personagem", um "cigano político", "hábil atleta" que fazia do preto, branco; Vasconcelos era o "Mirabeau brasileiro"91. "Gênio pérfido e intrigante" era a expressão com que o deputado mineiro Teófilo Otoni brindaria Vasconcelos. ${ }^{92}$ Os progressistas também denunciavam a "bula das circunstâncias" e o "governo das transações", por que os regressistas haviam conseguido desidratar em seu proveito a antiga base de sustentação do governo Feijó. Para o senador mineiro José Bento Ferreira de Melo, a política de Vasconcelos era "aterradora e dominada por espírito de vinganças miseráveis"; seu colega governava inspirado por "um espírito reator", de "prodigalidade e de patronato o mais escandaloso"93. 0 colega progressista de Ferreira de Melo, o senador paulista Nicolau de Campos Vergueiro, também condenava o "sistema do regresso" como a entronização da razão de Estado e, como tal, a imoralidade erigida em sistema: "A bula das circunstâncias, exprimindo a dispensa das leis, segundo as circunstâncias, estabelece em teoria a falta de respeito às mesmas leis, sem o qual não pode ser mantida a liberdade do cidadão". Na contramão de Vasconcelos, Vergueiro defendia a ética na política: "Negar os princípios absolutos em política e em moral é negar a estabilidade do temor de Deus, que é o princípio da sabedoria e de todo o bem na ordem moral; posto assim em contingência o princípio da moral, vacilante fica toda a política, que nenhum apoio firme pode ter fora da base da moral" ${ }^{\text {" }}$. Na mesma toada, o senador cearense José Martiniano de Alencar declarava que o "sistema do regresso, que eu chamo de reação, é o sistema das transações, que muitos chamam de corrupção"95. Na Câmara, o deputado Francisco Montezuma, futuro Visconde de Jequitinhonha, também acusava Vasconcelos de se orientar conforme os exemplos de Calígula e de Maquiavel que, "para governar, ao amor preferem o medo"96. 
97

MONTESQUIEU. Do Espirito das Leis. Introdução e Notas de Gonzague Truc. Tradução de Fernando Henrique Cardoso e Leôncio Martins Rodrigues. Volume II. São Paulo: Abril Cultural, 1979. p.202.

98

STAROBINSKI, Jean. Ação e Reação:vida e aventuras de um casal. Rio de Janeiro: Civilização Brasileira, 2002. p.283.

99

CONSTANT, Benjamin. De la Force du Gouverment Actuel de la France et de la Necessité de s'y Rallier; Des Réactions Politiques; Des Effets de la Terreur. Préface e notes de Phillipe Raynaud. Paris: Flammarion, 1988. p.95.

100

Ibidem, p.99.

\section{1}

ANAIS DA CÂMARA DOS DEPUTADOS. Op. Cit., sessão de 20 de julho de 1838.

\section{Os sentidos do regresso brasileiro: reação ou progresso?}

A esta altura da exposição cumpre indagar se o regresso pode ser de fato considerado uma reação. Embora constituam pares conceituais diversos, há inegavelmente uma associação entre ação e reação, de um lado, e progresso e regresso, de outro. No século XVIII, o ideal clássico de governo moderado ou misto, oriundo da Antiguidade, passou a ser perseguido a partir das categorias mecanicistas de equilibrio entre diferentes vetores, capazes de balancear movimentos da ação e da reação. Basta recordar a importância que na descrição da Constituição da Inglaterra operada por Montesquieu adquirem as imagens dos poderes separados e equipolentes, mantidos equilibrados por freios e contrapesos. ${ }^{97}$ Da mesma forma, a crença na possibilidade de intervir na ordem natural do mundo para garantir o bom governo, pelo exercício da vontade ilustrada, está igualmente associada ao equilíbrio por que aquela ação deveria ser conduzida. 0 desenvolvimento de uma filosofia da história como progresso constante e indefinido ao longo do tempo, por sua vez, introduziu novos requisitos ao equilibrio do bom governo. Representando uma etapa diferente e superior à anterior pelo esclarecimento progressivo da opinião pública, cada época exigiria instituições políticas flexíveis e adequadas que acompanhassem a evolução social. ${ }^{98}$

Nessa matéria, a referência intelectual mais difundida pelos liberais em geral era o panfleto Das Reações Políticas, escrito por Benjamin Constant durante o Termidor (1797). Para Constant, a arte finória da política consistiria em erigir um arcabouço institucional, ao mesmo tempo sólido e flexivel. Ele deveria ser sólido o bastante para garantir o Estado liberal, mas flexivel o suficiente para que ele acompanhasse as mudanças sociais. Era este o segredo para conduzir de forma segura o movimento, ou a ação, entendida como progresso histórico. A correspondência entre as instituições e o estado social era a ferida por sua recíproca congruência no plano intelectual: para que houvesse estabilidade, era preciso que as instituições estivessem "no nivel de suas ideias". Desde que se mantivesse a correlação entre instituições e estado social, aferido pelas ideias nele disseminadas, não haveria revoluções. Quando, ao contrário, "o acordo entre as instituições e as ideias se encontra destruído, as revoluções são inevitáveis". Quando as revoluções cumpriam logo o seu objetivo, o de restabelecer a correlação entre instituições e expectativas sociais, elas terminavam logo e bem. Era o que acontecera nos Estados Unidos. Quando, no entanto, a revolução estabelecia "instituições que estão além das ideias reinantes, ou destrói as que Ihe são conformes", elas produziam as "reações"99. Ou seja, as reações políticas resultavam dos excessos da revolução, quando ela ia além do desejado pela sociedade. Pretender, porém, retornar ao passado, era tão inútil quanto querer adiantar o futuro. Por isso, cumpria aos liberais "impedir que o movimento retrógrado, que inevitavelmente sucede ao uma impulsão excessiva, não se prolongue além dos limites necessários" ${ }^{100}$.

Com esse referencial teórico em mente, os liberais brasileiros não manifestavam dúvidas a respeito do caráter reator do movimento regressista. 0 deputado paulista Álvares Machado comentava na Câmara: "Eu não sei para onde vamos marchando. Para a liberdade, não; o ministério já o disse, para o regresso"101. Em outras palavras, o regressismo era uma política que conduzia o país de volta ao absolutismo. No Senado, o cearense José Martiniano de Alencar descrevia o regresso como um "sistema de reação" por que Vasconcelos pretendera "levar as cousas todas ao antigo regime, ao que dominava antes do 7 de abril", promovendo "todas 
102

Ibidem, sessão de 28 de maio de 1839. 0

"sistema de reação" a que os liberais no Senado e na Câmara se referiam aludia às demissões determinadas por Vasconcelos do pessoal vinculado à ala esquerda do antigo Partido Liberal Moderado nas províncias, que provocara enorme alarido.

103

ANAIS DO SENADO DO IMPÉRIO. Op. Cit., sessão de $1^{\circ}$ de agosto de 1839.

104

ANAIS DO SENADO DO IMPÉRIO. Loc. Cit.

105

Ibidem, sessão de 2 de setembro de 1839 .

106

Ibidem, sessão de 29 de maio de 1839. as perseguições contra os homens conscienciosos que não mudaram de opinião"102. Eis por que a cena política se achava polarizada entre aqueles que queriam o progresso, e aqueles que, querendo o regresso, pretendiam retomar as práticas do Primeiro Reinado, quando não do Antigo Regime:

\begin{abstract}
Hoje, no Brasil, dois pensamentos opostos se combatem: as ideias a favor do progresso da liberdade - que apareceram com a reforma da Constituição e vigoraram de 1831 até 1837 -, e as ideias que parecem mostrar arrependimento desse progresso e desejos de retrogradação, criando uma nova ordem de coisas, talvez ainda menos favoráveis à liberdade do que aquela que existia antes de 1830. Esses dois pensamentos estão em campo no Brasil, bem como outrora na Europa se combatiam os dois princípios da legitimidade dos reis, uns querendo que essa legitimidade fosse emanada do direito divino, e outros da soberania nacional. 0 ministério de 19 de setembro [chefiado por Vasconcelos] pareceu seguir o sistema do arrependimento ou do regresso; seus projetos tendiam todos a este fim, e em consequência reconheceu que não podia reger o Império senão com leis excepcionais, com créditos extraordinários, e enfim pela força, pelo arbitrio. ${ }^{103}$
\end{abstract}

0 senador maranhense Costa Ferreira também se encarregava de desmentir a tese segundo a qual o regresso era o verdadeiro progresso: "Os que têm pregado as doutrinas do regresso chamam-se progressistas e, no entanto, vão procurando minar as instituições liberais"104. Envolvido nas maquinações dos liberais pela antecipação da maioridade legal do Imperador menino, o Marquês de Paranaguá também sustentava a impossibilidade do regresso, já que o espírito humano não retrogradava:

\footnotetext{
Quanto se engana quem se persuade no estado atual do mundo, de que é possíve fazer retrogradar o espírito humano! Poderá, não duvido, alterar-se a nova ordem das coisas, poderá mesmo ser outra mui diferente, mas tornar-se a ser o que foi, é impossivel; mortos não ressuscitam. Senhores! Mal vai o homem de Estado que não faz caso das ideias dominantes, pois que é só com elas, e marchando a par delas, que se pode governar em paz e com glória, e fazer a felicidade pública. Cumpre mesmo tolerar as mais exageradas, respeitá-las até certo ponto, e não querer destruí-las a pancada. ${ }^{105}$
}

Os regressistas, porém, recusaram-se a encampar o argumento de que o seu movimento fosse reacionário como aqueles sustentados na Europa pelos miguelistas portugueses ou pelos carlistas espanhóis. A crítica regressista do "progresso" enquanto espírito de inovação não refutava a filosofia da história enquanto progresso da liberdade, limitando-se a questionar o modo acrítico e a velocidade excessiva com que se pretendera até então favorecê-la num meio adverso como o brasileiro. Os defensores do regresso não o apresentavam como a negação do liberalismo, mas como uma correção de rumos destinada a criar, pelo estabelecimento da ordem, as condições necessárias à aclimatação da liberdade no Brasil. Para Vasconcelos e seu grupo, o movimento regressista não se processava contra ou fora do liberalismo, e sim no seu interior e ao seu favor. Não era correto, pois, qualificar o regresso como uma reação, nos termos definidos por Constant: "Regresso não quer dizer voltar aos tempos da antiga monarquia", advertia Vasconcelos. ${ }^{106}$ Esse caráter liberal do movimento reaparecia na alocução do deputado Carneiro Leão, ao longo do qual ele expôs sua convicção de que regressistas e progressistas estavam de acordo sobre o que pretendiam - a consolidação da monarquia constitucional brasileira - , divergindo somente quanto aos meios. Por isso, os regressistas não poderiam ser atacados como defensores do absolutismo, sendo tão liberais quanto seus adversários: 
107

Ibidem, sessão de 5 de setembro de 1839 .

Nós divergimos de meios; queremos todos a integridade do Império, queremos todos a manutenção das instituições; queremos todos banir a guerra civil que existe entre nós. Mas aqueles que, para conseguir aquele grande fim comum, divergem dos meios do nobre orador (o liberal Alvares Machado) não podem decerto ser taxados de pretensão de quererem restabelecer o despotismo. Isto é na verdade grande injustiça. Estou convencido de que a experiência feita sobre algumas leis tem apresentado entre nós resultados diferentes do que se desejava, mas não se segue daí que se devam rejeitar as instituições e que se passe de um extremo a outro. Essas leis podem ser emendadas e acomodar-se melhor às circunstâncias e civilização do país. ${ }^{107}$

Assim, os regressistas não abdicavam da concepção da história entendida como marcha do progresso para a liberdade. 0 que se alegava era que o equilíbrio entre as forças da ordem e do progresso se desfizera pelo excesso de ênfase conferida a este último elemento pelos liberais, na forma de uma aceleração que o estado do país se revelara incapaz de assimilar. Eis por que urgia interromper aquele processo e recuar para um ponto anterior, a fim de retomá-lo depois de modo prudente. Assim entendido, o regresso era um progresso porque, restabelecido o equilibrio entre a autoridade e liberdade, seria possivel no futuro retomar a marcha da liberdade em condições mais favoráveis. No frigir dos ovos, o que Vasconcelos fazia era operar uma verdadeira mutação conceitual, pela qual o regresso se tornava sinônimo de progresso - o verdadeiro progresso.

Diz o amigo do progresso: quem nos deve governar é o pais, o governo de si mesmo é o único governo que convém a homens civilizados. E o que desejo eu? É que, quando se apresente algum boato arreado com o nome de opinião pública, que procuremos examiná-lo, consultemos todos os sentimentos, todas as opiniões, todos os interesses, e depois de termos procurado chegar ao verdadeiro conhecimento dos verdadeiros interesses do país, tanto pela discussão espontânea, como pela discussão oficial, conheçamos então a opinião pública, então obedeçamos aos seus decretos. Perguntarei: quem professa tais ideias [de regresso] é ou não progressista? 0 que pode desejar o amigo do progresso? Não será o que venho de expender?. ${ }^{108}$

108

ANAIS DA CÂMARA DOS DEPUTADOS. Op. Cit., sessão de 23 de maio de 1838 .

109

Pouco depois Andrada Machado romperia com Vasconcelos e se juntaria aos antigos liberais, combatendo o regresso que apoiara. A atitude the rendeu frutos, pois chefiou o primeiro gabinete - liberal, naturalmente - organizado depois do golpe da maioridade.

110

ANAIS DA CÂMARA DOS DEPUTADOS, sessão de 23 de maio de 1838.
Raciocínio análogo ao de Vasconcelos era aquele expedido pelo deputado paulista Antônio Carlos de Andrada Machado ${ }^{109}$ para convencer um colega que, dizendo-se progressista, verberava contra o movimento regressista. Estava na hora de parar de jogar com as palavras: se o regresso era o verdadeiro progresso, como de fato era, aqueles que acreditassem na perfectibilidade humana deveriam abraçá-lo. Se o liberal fosse verdadeiramente amigo do progresso, deveria aderir ao regresso - do contrário não seriam nem liberais, mas estacionários:

Sendo o nobre deputado sectário e crente na perfectibilidade da espécie humana e, por conseguinte, tendo apregoado o sistema do progresso, não compreendo como queira agora ser estacionário. Estacionário por algum tempo, concedo eu, a prudência o aconselha e a sabedoria ordena, mas estacionário todo o tempo, não entendo. A natureza viva está sempre em movimento; tirar-lhe este movimento é petrificá-la, é reduzi-la à morte. Tem-se dito muitas vezes, e não era talvez preciso repetir, que não estamos nos tempos dos escolásticos, que não há aqui a seita de nominais e reais. Se o regresso nos aproxima da meta desejada, é um verdadeiro progresso; se nos arreda desta meta, então é um regresso que se não deve admitir, porque nós somos entes perfectiveis, desejamos a felicidade do pais, para o que tudo caminha e para o que as instituições nos abrem a estrada. ${ }^{110}$ 
111

Refiro-me aqui ao conservadorismo tal como definido por um de seus explicadores - possuidor de origens feudais ou medievais, defensora da descentralização do poder e das tradições de vida autônomas do povo. Cf. NISBET, Robert. Conservadorismo. Madrid: Alianza Editorial, 1986. p.65. Não entendo como, no século XIX, fosse possivel houvesse na América Ibérica um conservadorismo dessa natureza, já que nela não se tinha vivido o feudalismo ou uma Idade Média; se era preciso um Estado centralizado para implantar a ordem nacional até então inexistente e sequer se reconhecia a existência de uma comunidade politica moderna. Tudo estava por ser criado e só o poderia ser pelas mãos de suas elites modernas no comando do Estado. Neste sentido, o conservadorismo liberal ibero-americano parece ter tido mais identidade com o reformismo ilustrado do que se imagina à primeira vista.

112

"As duas grandes tendências politicas (chilenas) do século XIX - liberais e conservadores alentaram grupos definiveis todos eles como 'liberais' na medida em que postulavam a república como o melhor sistema de governo e a Constituição como instrumento para regular a vida em sociedade. Não houve intentos relevantes surgidos entre políticos chilenos de restaurar a monarquia espanhola nem posições 'conservadoras' no sentido restauracionista que contemplavam os grupos mais tradicionais na Europa". Cf. SAN FRANCISCO, Alejandro; MOYANO, Cristina. El liberalismo em Chile em el siglo XIX: la formacion del concepto, su trayectoria y sus dimensiones. In: FERNANDEZ SEBASTIAN, Javier. La Aurora de la Liberdad: Ios primeros liberalismos en el mundo iberoamericano. Madrid: Marcial Pons Historia, 2012. p.148.

113

SUANZES-CARPEGNA, Joaquín Varela. Op. Cit. p.94.

114

OLABARRÍA AGRA, Juan. Moderado. In: FERNANDEZ SEBASTIAN, Javier; FUENTES, Juan Francisco (dirs). Op. Cit., p.450.

115

LYNCH, Christian Edward Cyril. Da Monarquia à Oligarquia. Op. Cit., p.60.

\section{Conclusão}

Este artigo sugere a dificuldade de se interpretar os movimentos conservadores na América a partir da categoria clássica de reação. Isto parece particularmente verdadeiro na sua porção ibérica, onde a percepção do atraso e do caráter negativo do Antigo Regime tornou particularmente problemática a defesa do conservadorismo clássico vigente na Europa no século dezenove. ${ }^{111} 0$ retorno ao Antigo Regime significaria sem mais nem menos restauração do estatuto colonial. A recusa do liberalismo importaria negar o próprio processo de independência, de que ele havia sido o produto mais valioso. É o que parece explicar por que o movimento regressista não pode ser apresentado como uma reação, entendida como partidária do absolutismo - tal como em Portugal os miguelismo e, na Espanha, os carlismos. Os conservadores brasileiros, como os chilenos, também se achavam no interior do espectro político liberal. ${ }^{112}$ Que a América parecia fadada ao liberalismo, era algo de que eles não duvidavam. E eram eles - e não os autointitulados liberais - que, garantindo a ordem e as instituições, semeariam os meios para que para o futuro a árvore da liberdade pudesse medrar.

Arriscando um passo adiante, seria possível ainda indagar se, no Novo Mundo ibérico, o discurso conservador não foi inclusive obrigado a mostrar maiores credenciais de comprometimento com o progresso do que em suas antigas metrópoles. Uma comparação entre os saquaremas brasileiros das décadas de 1830 e 1840 com os moderados espanhóis parece confirmar essa hipótese. Estes tinham como pedra de toque as teses relativas ao caráter histórico do constitucionalismo e ao caráter compartiIhado da soberania entre a Coroa e o Parlamento. ${ }^{113} \mathrm{Em} \mathrm{1833,} \mathrm{Alberto} \mathrm{Lista}$ enunciara as pedras de toque ideológicas do partido moderado espanhol: positivismo institucional, por meio do qual a legitimidade decorria do governo por sua própria existência, e não do povo; historicismo, por meio do qual era legítimo o governo que se ancorava no passado histórico, ancorando um nacionalismo conservador; o economismo, segundo o qual não era possivel haver progresso político sem prévio progresso econômico; e o justo meio, entendido como equidistância entre absolutismo e anarquia. ${ }^{114}$

Ora, embora também defendessem a monarquia constitucional, os conservadores brasileiros não abriam mão da soberania nacional que aqui era o seu fundamento. Ao invés do positivismo institucional, eles recorriam a uma justificação de estilo napoleônico - a aclamação do Imperador depois da independência - para justificar a primazia do Executivo no sistema constitucional. E isto porque, constitucionalmente, os poderes do monarca também radicavam na soberania nacional; ele também era definido como "representante da Nação". Também não viam valia no recurso ao historicismo: considerando o Brasil demasiado jovem e atrasado, preferiram argumentos de ordem sociológica, enfatizando o estado semibárbaro do país para justificar a adaptação do liberalismo e a centralização política. ${ }^{115}$ Quanto ao economismo, a dimensão civilizadora do Estado foi sempre pensada pelos conservadores mais em termos culturais do que econômicos. Também a defesa do justo meio entre 0 absolutismo e o liberalismo não era efetuada nos mesmos termos, porque no Brasil não havia um partido absolutista como na Espanha. Mais do que com os moderados espanhóis (a direita constitucional), os conservadores brasileiros pareciam ter mais afinidades com os progressistas (a centro-direita) que haviam patrocinado a Constituição compromissória de 1837. Ambos os partidos estavam em- 
116

SUANZES-CARPEGNA, Joaquin Varela. Op. Cit., p.83.

117

Assim, por exemplo, no Chile de 1842, explicava o jovem José Victorino Lastarria a necessidade de se postergar o ideal democrático: "A democracia, que é a liberdade, não se legitima, não é útil nem benfazeja, senão quando o povo chegou em sua idade madura, e nós não somos ainda adultos. A força que deviamos ter empregado para adquirir essa maturidade, que é a ilustração, esteve submetida por três séculos a satisfazer a cobiça de uma metrópole atrasada e mais tarde ocupada em destruir os grilhões e constituir um governo independente. A nós toca voltar atrás para preencher o vazio que deixaram nossos pais e fazer mais consistente a sua obra, para não deixar inimigos por vencer, e seguir com pé firme a senda que nos traga o século". In: SAN FRANCISCO, Alejandro; MOYANO, Cristina. Op. Cit., p.168.

118

ANAIS DA CÂMARA DOS DEPUTADOS. Op. Cit., sessão de 5 de julho de 1838.

119

ANAIS DO SENADO DO IMPÉRIO. Op. Cit., sessão de 3 de julho de 1871. bebidos do liberalismo doutrinário francês; ambos defendiam a soberania nacional e os direitos fundamentais; mas diluiam sua aplicação estrita pela crítica da metafísica revolucionária, pela substituição da razão abstrata pela experiência como base da política e por uma visão de mundo estribada em um realismo sociológico, de fundamento cético e utilitário. ${ }^{116}$

Tudo parece apontar, portanto, para o fato de que, comparados aos moderados espanhóis, os regressistas brasileiros foram obrigados a afetar mais aderência aos principios progressistas, ou liberais. Também por esses motivos, parte significativa dos conservadores ibero-americanos justificou a sua guinada à direita como um expediente pragmático, destinado a excepcionar temporariamente a plena aplicação do liberalismo em seus paises naquela quadra inicial de suas vidas independentes. Num continente periférico, atrasado, mas condenado à civilização, voltado para o futuro, não era possivel pensar o "regresso" fora da filosofia da história como progresso; ele somente poderia ser justificado enquanto medida transitória e circunstancial. ${ }^{117} 0$ próprio Vasconcelos não deixou dúvidas a este respeito quando alegou que o aparente arbítrio praticado por seu governo era uma medida excepcional, necessária para garantir, pela consolidação da ordem nacional, as condições futuras de civilização do país:

0 ilustre deputado disse que não honra a ministério algum emitir uma tal opinião [pretender dinheiro, baionetas e tribunais privativos]; que a honra de um ministério consiste em asseverar que quer estabelecer a liberdade no seu país; que não quer arbítrio, que quer promover os recursos do pais para que, participando de todos os aperfeiçoamentos morais, goze de todas as vantagens da civilização. Mas o que quero eu, nas circunstâncias extraordinárias em que se me afigura o país? Se quero baionetas, quero dinheiro, quero tribunais privativos, é para este mesmo fim. ${ }^{118}$

De fato, quando os próprios conservadores se encarregaram de revogar uma das mais importantes leis do regresso, em 1871, um ex-conservador, àquela altura tornado chefe liberal - o senador José Antônio Saraiva -, recordou no plenário que aquela medida havia sido concebida como um expediente transitório para combater as desordens das guerras civis. No seu entender, nenhum conservador, muito menos Vasconcelos, poderia imaginar que ela duraria tanto tempo:

\footnotetext{
Não quero condenar nem fazer a menor censura aos autores da lei de 3 de dezembro. Estou convencido de que eles acreditaram muito profundo o mal do pais naquela época, para fazer semelhante lei de reação. Mas o certo é que na opinião de muitos dos deputados e senadores que votaram a lei de 3 de dezembro, esta lei era uma lei provisória, uma medida passageira, uma suspensão de garantias mais ou menos aconselhada pelas graves circunstâncias do Brasil. Era uma medida extraordinária; e todos os que votaram a lei o fizeram com o propósito firme de a revogar, logo que as circunstâncias do país fossem outras. (...). Eu não me admiro, pois, de que o partido conservador trate de reformar a lei; o que admiro é que ele próprio não tenha feito isto há mais tempo. ${ }^{119}$
}

A percepção de um maior atraso social, combinado com a sensação de extrema juventude do país e falta de um passado a que se pudesse apelar para legitimar o sistema político, criava um ambiente que favorecia, de modo mais amplo que na Europa, a ideia de uma fuga para o futuro. 0 resultado foi assim, não só a impossibilidade de uma reação absolutista, mas o maior comprometimento ideológico da classe política em geral e dos conservadores ibero-americanos em particular com perspectivas - formal- 
120

Confira-se a este respeito a obra-prima de GUERRA, François Xavier. Le Mexique: de l'Ancien Régime à la révolution. Paris: L'Harmattan, 1985. mente ao menos - mais progressistas do que aquelas de seus congêneres europeus. Já que a ausência de feudalismo e a condição colonial anterior impediam a existência, à direita, de uma corrente absolutista tradicionalista, o imaginário político era impelido mais fortemente para a esquerda, para o futuro - ainda que as condições efetivas de sua efetivação fossem muito mais precárias do que no Velho Mundo. Neste caso, a adoção formal de instituições ultramodernas que ficariam em larga medida ineficazes no plano da realidade - a conjugação de modernidade formal e conservadorismo prático - se nos afigura um fenômeno lógico, que daria origem a uma intrincada prática política na periferia ibero-americana. ${ }^{120}$ 